\title{
Examining the Level of Service in the Context of Recreational Carrying Capacity in the Erzurum Urban Forest, Turkey
}

\author{
Tendü Hilal Göktuğ' ${ }^{*}$, Nalan Demircioğlu Yıldız², Metin Demir², Burcu Mestav \\ ${ }^{1}$ Department of Landscape Architecture, Agriculture Faculty, Adnan Menders University, South Campus, Aydın, \\ Turkey \\ ${ }^{2}$ Department of Landscape Architecture, Architecture and Design Faculty, Atatürk University, Erzurum, Turkey \\ ${ }^{3}$ Department of Statistic, Arts and Sciences Faculty, Çanakkale on Sekiz Mart University, Terzioğlu Campus, \\ Çanakkale, Turkey \\ Email: ${ }^{*}$ tendugoktug@hotmail.com
}

Received 30 July 2015; accepted 12 September 2015; published 15 September 2015

Copyright (C) 2015 by authors and Scientific Research Publishing Inc.

This work is licensed under the Creative Commons Attribution International License (CC BY).

http://creativecommons.org/licenses/by/4.0/

(c) (i) Open Access

\begin{abstract}
Urban forests are confronted with high using pressure because of the increasing demand for recreation and accessibility of these settings. For that purpose, defining and managing recreational carrying capacity is considered as significant in ensuring ecological value's and recreational satisfaction's continuity. The purpose of this paper is to investigate the carrying capacity of Erzurum Urban Forest with respect to Level of Service (LOS) as a new management technique that focuses on service quality and visitor satisfaction. The data were obtained by self-administered questionnaire conducted with 166 visitors on weekends and holidays during summer season of the year 2014. Data were analyzed by dimensions/indicators of recreational satisfaction and socio-demographic characteristics with intent to identify tolerance range of visitors. The contribution and relative importance of each of the indicators to the overall satisfaction were analyzed by using Ordinal Logistic Model (OLM). The results indicated that the four indicators were at the greatest degree; "distance from picnic spot to toilets" and "quantity of children's playground facilities" were decease of overall satisfaction while "distance from picnic spot to parking" and "level of shade at picnic spot" had a positive contribution to the overall satisfaction. The outputs from these analyses were used to calculate LOS. It was revealed that the level of service (0.40) in Erzurum Urban Forest was below the moderate level. Planning and managing strategies for optimizing the LOS were developed and discussed by considering these results.
\end{abstract}

${ }^{*}$ Corresponding author.

How to cite this paper: Göktuğ, T.H., Yıldız, N.D., Demir, M. and Mestav, B. (2015) Examining the Level of Service in the Context of Recreational Carrying Capacity in the Erzurum Urban Forest, Turkey. Journal of Environmental Protection, 6, 1014-1028. http://dx.doi.org/10.4236/jep.2015.69090 


\section{Keywords}

\section{Recreational Carrying Capacity, Level of Service, Visitor Satisfaction, Recreation Planning and Management, Erzurum Urban Forest}

\section{Introduction}

Outdoor recreations are widely recognized as an important element in people's lives [1] [2]. Today there are large numbers of people using urban forests for their recreation. Urban forests not only provide physical and biological benefits, but also contribute to human well-being in urban environments by offering refuges from hectic city life and the work environment [3]-[5]. At the same time, these parks are confronted with high use pressure because of the increasing demand for recreation and accessibility of urban forest settings [6]. One main challenge for the forests' management is to contend with negative impacts of visitor use on both natural environment and visitors' recreational experience [7] [8]. For that purpose, forest managements strive to balance preservation and use to investigate the acceptable level of recreational use that can be sustained by the environmental resources of the recreational forest area [9]. This effort has often been mentioned as defining and managing recreational carrying capacity [10]. The main purpose of this research is to analyze the carrying capacity of Erzurum Urban Forest with using Level of Service (LOS) as a new management technique that focuses on recreation experience [11]. The study has three goals in the scope of main purpose. The first goal of this study is to identify, on the basis LOS concept, the tolerance range of indicators that are functions components of satisfaction. The second goal is to identify indicators, which are more effective on overall visitor satisfaction in Erzurum Urban Forest and the third goal is to calculate LOS and bring forward a proposal on planning and management.

Carrying Capacity: In its most generic form, carrying capacity refers to the amount of activity or use that can be accommodated in recreational settings before it begins to deteriorate. Another way to describe carrying capacity is determining maximum use level that recreational settings can absorb, before unacceptable impacts occur [12]. It was recorded the first recommendation for applying the concept of carrying capacity to outdoor recreation in the mid-1930's as a park management concept. But the development of recreation carrying capacity concept started with Wagar's (1964) [13] monograph and subsequent paper on the topic, which Wagar indicated as the more recreational use could affect, not only the natural and cultural resources values of the area but also the quality of recreational experience [14]. From this point of view, 4 dimensions (Physical, Social, Ecological and Managerial) of carrying capacity were identified in the process of time. Physical capacity is defined as the maximum number of visitors occupying specific areas, numbers of parties per site and the physical characteristics of sites and percent occupancy for various facilities. Social capacity is the maximum visitor use above which there is a decline in the quality of the recreation experience. This component is concerned with social impacts, such as visitors' perceptions of crowding. Ecological carrying capacity is the maximum level of visitor use, which can be accommodated by an ecosystem before an unacceptable or irreversible decline in natural and cultural values such as the loss of ground cover, impacts on wetlands and riparian communities, observed soil compaction and soil erosion, and observed trash accumulation and sanitary problems. Management capacity is defined as the maximum number of visits that a site can sustain considering the administrative facilities. It can also be defined as the level of use of a site that is required to yield a given financial return and also as the amount of income that local people provide by tourism/ecotourism [2] [9] [15] [16]. Determining carrying capacity is linked with the practical problems involved in difficultness of absolute measurable conditions [12] [17]. The capacity of a park also varies depending on the place, season, time, user behavior, facility design, patterns and levels of management, and the dynamic character of the environmental elements [18]. In spite of these severe challenges, carrying capacity is accepted as a useful concept for determining desirable conditions, unacceptable impacts and use levels that affect conditions [19].

Planning and Management Frameworks: A number of planning and decision-making frameworks were developed by researchers to help planners and managers with address visitor impacts or capacity, including Recreation Opportunity Spectrum (ROS) [20]; Limits of Acceptable Change (LAC) [21]; Visitor Activity Management Process (VAMP) [22]; Carrying Capacity Assessment Process (C-CAP) [15]; Visitor Impact Management (VIM) [23] and Visitor Experience and Resource Protection (VERP) [24]. Although all frameworks differ 
from each other in terms of orientation, emphasis, terminology and specific steps are also the common traits [25]. All these frameworks suggest the necessity of measuring indicators to elicit standards of quality for acceptable conditions [26]. Manning et al. (1996) [27] identified that indicators of quality were specific, measurable variables that defined the quality of the recreation experience. Standards of quality define the minimum acceptable condition of each indicator variable. Outdoor recreation can be functionally planned, monitored, and managed with defining indicators and standards of quality. Facilities and services for visitors can be planned to ensure that the standards of quality are met [28]. Overall visitor satisfaction is a function of various indicators, which are components of recreational services and facilities, natural and cultural resources and recreational use levels [29]-[34]. In a sense, the visitor satisfaction is a function of the multiple features of the natural, social and managerial environment, and recreational activity [35]-[38]. By defining indicators and standards of quality, recreational areas can be pleasingly planned, monitored, and managed. Also, indicators of quality can be monitored over time, and if appropriate, management action can be taken in a way not to exceed standards of quality [11]-[32]. In an attempt to estimate the total visitor satisfaction of visitors, Fleishman and Feitelson (2003) [11] adapted Level of Service (LOS) to recreation areas as a new management technique. The LOS concept was first developed for transportation system. Since then, this method has been developed for pedestrian flows, bicycle flows, pedestrian walkways and viewing platforms of National Park [39] and also forest based recreation [11]. Overall user satisfaction is an important criterion for determining level of service [40] [41]. It is a function of overall satisfaction from each of the service components according to its relative importance for the visitors [32] [42]. This method is based on measured and monitored indicators, which are used to determine visitor satisfaction. This approach enables to determine the values of each of the indicators and their contribution to the overall satisfaction of visitors, who are involved in a particular recreational activity quantified.

\section{Material and Methods}

Study Area: Erzurum Urban Forest is located $5 \mathrm{~km}$ South West of the city center of Erzurum (Figure 1). The park is situated on steep with an area of 717 ha. The forest, surrounded by both planted and natural woodlands, which are mainly Pinussylvestris and Betula pendula and Salix alba. In this urban forest, approximately 1075.5
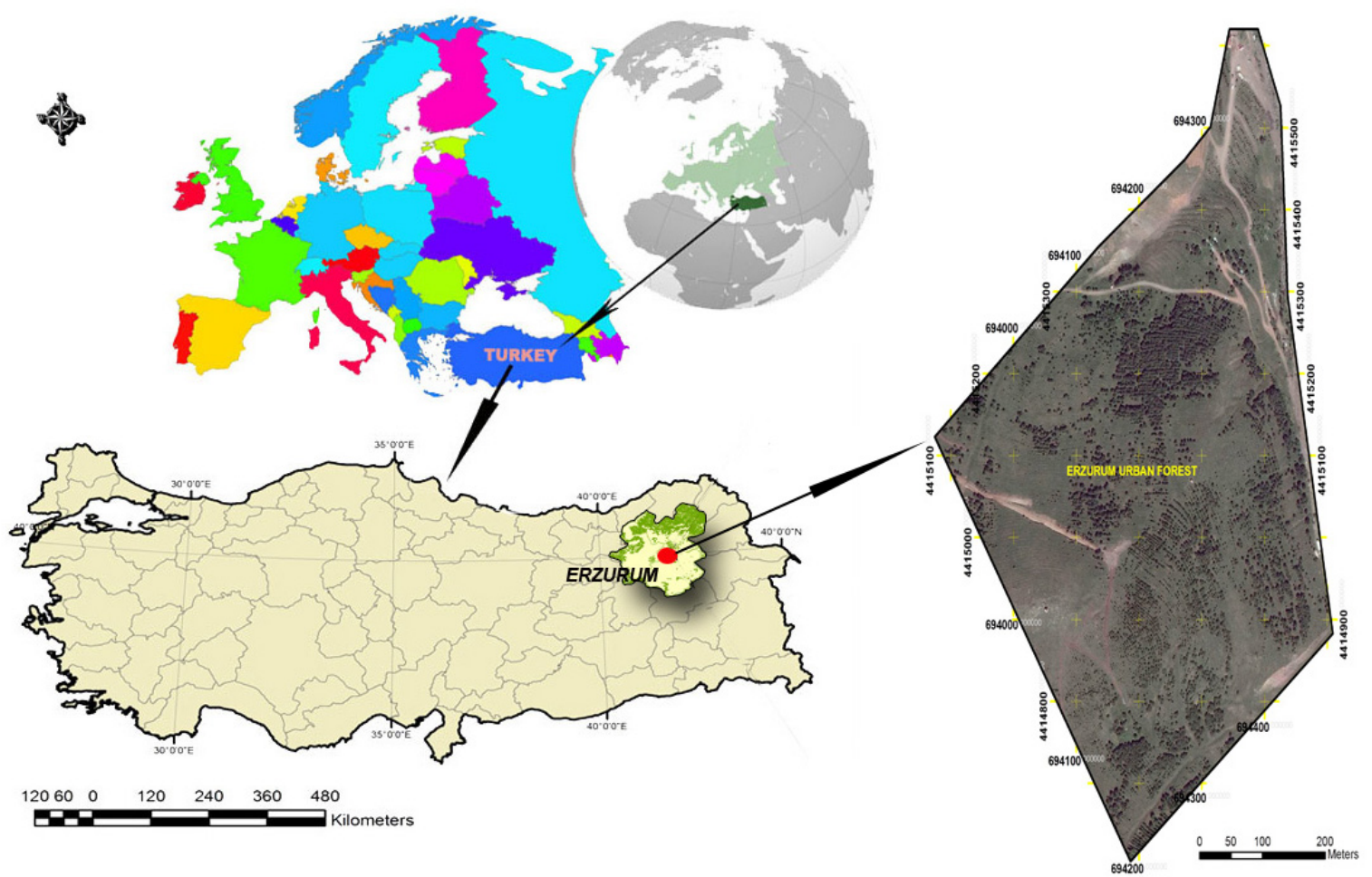

Figure 1. Location of forest. 
tons of carbon is stored. This corresponds to 3943.5 tons of carbon dioxide in the atmosphere. The avifauna in the park area includes pigs, foxes, moles, squirrels, rabbits [43].

According to the accounting records, the average of the last 4 years, the annual number of visits to the area is 11000. The major recreational activity in the forest is picnics. Most use occurs during summer, because of the higher and more comfortable daytime temperature. The forest is equipped with recreation facilities, including picnic areas, observation terrace, spring and children's playgrounds (Figure 2). There are 2 pergolas, 23 picnic tables, 2 toilet units, 1 playground and 16 rubbish bins. Erzurum Urban Forest managed by Erzurum Regional Directorate of Forestry, The forest primarily serves the local people of Erzurum City in the vicinity of the forest. Through the existing road network, the accessibility to the forest is easy [43].

Methods: The geographical, biological, physical, managerial characteristics and the annual visits of the research area were inquired. Data concerning the demographics and visitor satisfaction levels were collected using a questionnaire survey, administrated on-site on weekends and holidays during summer season of 2014, periods known to be the peak seasons. The onsite survey was conducted among private visitors, usually a group of family members and/or friends. The visitors sampled, over the age 18 , were asked to participate in the study and to fill out self-administered questionnaire. 166 were useable questionnaires from the 200 respondents sampled; the response rate was $83 \%$. The carrying capacity was assessed by using Level of Service (LOS) methodology, which was adopted by Fleishman and Feitelson (2009) [11]. This method comprises the following steps.

Identifying sources of satisfaction for a recreational activity: For the purpose of identifying the sources of satisfaction for a recreational activity such as picnics in forests, possible dimensions of satisfaction for picnic recreation in forests were delineated. These dimensions and the indicators, which were used for assessing this each of dimensions, are presented in the following Table 1.

Identifying the minimum acceptable level and ideal level of the tolerance range: In order to identify tolerance level it is necessary to identify the minimum acceptable level and the ideal level. Tolerance level represents the range between ideal level and minimum acceptable level. The minimum acceptable level of the tolerance range is a threshold leaving the recreational site earlier or choosing alternative recreational sites. This threshold is a function of visitors' individual traits. The ideal level means average suitable condition level for recreation. In order to identify minimum acceptable level and ideal level of the tolerance range generic method was implemented. This method based upon visitors' opinions on a request to specify the level of each indicator, which might cause displacement, and average suitable condition. Each of indicators' level of services (indicator levels and their scale of measurement) have been defined by Fleishman and Feitelson (2009) [11] according to the picnic activities in the urban forests as in Table 2.

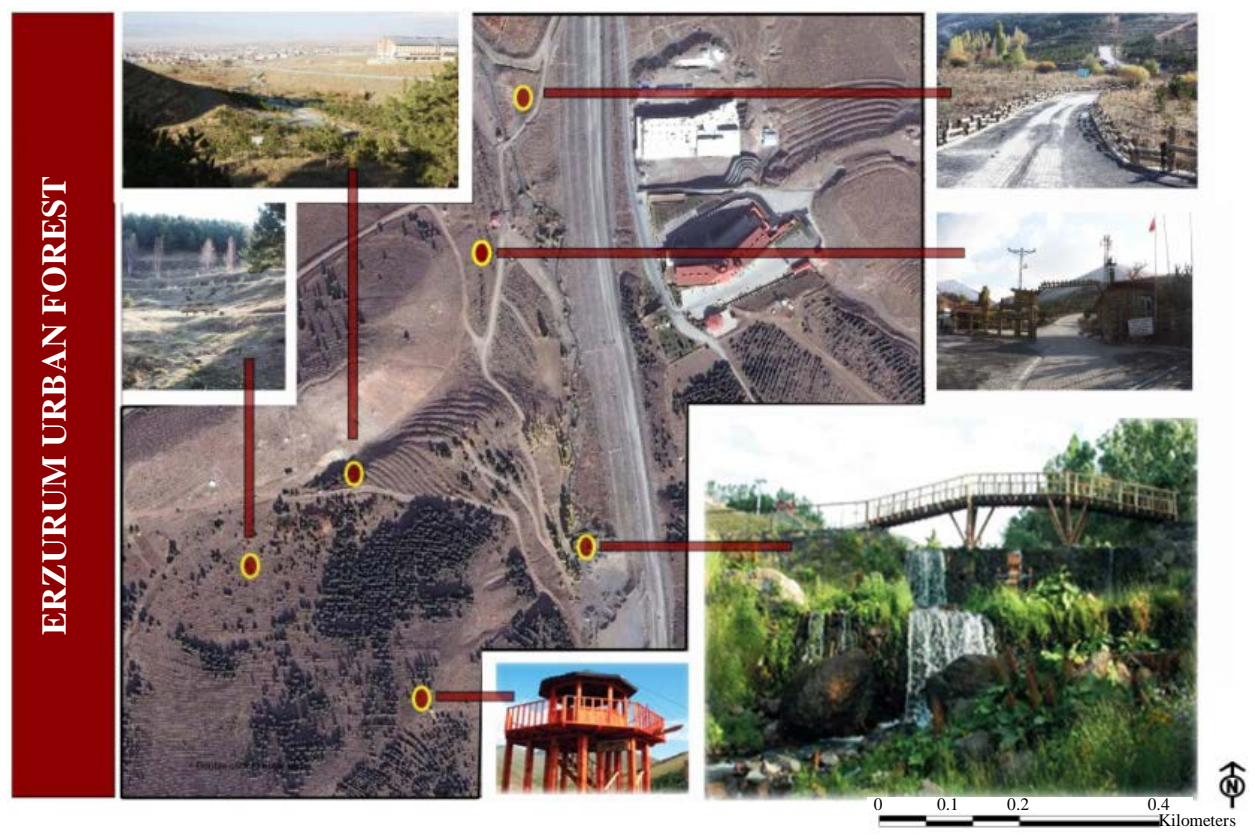

Figure 2. Recreational use map. 
Table 1. Dimensions and indicators for picnic recreation.

\begin{tabular}{|c|c|}
\hline Dimensions & Indicators \\
\hline \multirow{2}{*}{ Location, capacity and occupancy of the parking lot } & Time searching for a parking space. \\
\hline & Distance from picnic spot to parking. \\
\hline \multirow{4}{*}{ Location, number and quality of service facilities } & Time searching for a picnic spot. \\
\hline & Number of available picnic tables at picnic site. \\
\hline & Distance from picnic spot to adjacent group. \\
\hline & Quality and maintenance level of tables. \\
\hline \multirow{3}{*}{ Location, number, quality and access to sanitary facilities } & Quality and maintenance level of toilets. \\
\hline & Distance from picnic spot to toilets. \\
\hline & Distance from picnic spot to water taps. \\
\hline \multirow{5}{*}{ Number, quality and access to recreational facilities } & Quantity of children’s playground facilities. \\
\hline & Quantity of sport facilities. \\
\hline & Distance from signs to signs. \\
\hline & Quality and maintenance level of children playground facilities. \\
\hline & Quality and maintenance level of sport facilities. \\
\hline \multirow{2}{*}{ Cleanliness and shady vegetation in picnic area } & General cleanliness. \\
\hline & Level of shade at picnic spot. \\
\hline Level of personal security in the setting & Security level at site. \\
\hline
\end{tabular}

Table 2. Levels of service by indicators.

\begin{tabular}{|c|c|c|c|c|}
\hline \multirow{2}{*}{ Indicators } & \multicolumn{4}{|c|}{ Levels of service $^{\text {a }}$} \\
\hline & 4 & 3 & 2 & 1 \\
\hline Time searching for a parking space & Up to $5 \mathrm{~min}$ & $5-10 \min$ & $10-15 \min$ & More than $15 \mathrm{~min}$ \\
\hline Time searching for a picnic spot & Up to $5 \mathrm{~min}$ & $5-10 \min$ & $10-15 \min$ & More than $15 \mathrm{~min}$ \\
\hline Number of available picnic tables at picnic site & More than 2/3 & $2 / 3-1 / 3$ & $1 / 3$ & Less than a third \\
\hline Distance from picnic spot to adjacent group & More than $20 \mathrm{~m}$ & $10-20 m$ & $5-10 m$ & Up to $5 \mathrm{~m}$ \\
\hline Distance from picnic spot to parking & Up to $5 \mathrm{~m}$ & $5-15 m$ & $15-30 \mathrm{~m}$ & More than $30 \mathrm{~m}$ \\
\hline Distance from picnic spot to toilets & $20-40 m$ & $40-60 m$ & $60-100 m$ & More than $100 \mathrm{~m}$ \\
\hline Distance from picnic spot to water taps & Up to $5 \mathrm{~m}$ & $5-10 m$ & $10-20 m$ & More than $20 \mathrm{~m}$ \\
\hline Distance from signs to signs & $40-60 m$ & $60-100 m$ & $100-200 m$ & More than $200 \mathrm{~m}$ \\
\hline Quantity of children's playground facilities & 5 - 6 in area & $3-4$ in area & 1 - 2 in area & None \\
\hline Quantity of sport facilities & $5-6$ in area & $3-4$ in area & $1-2$ in area & None \\
\hline Quality and maintenance level of tables & $\begin{array}{l}\text { All tables clean } \\
\text { and whole }\end{array}$ & $\begin{array}{l}\text { Most tables clean } \\
\text { and whole }\end{array}$ & $\begin{array}{l}\text { Most tables dirty } \\
\text { and broken }\end{array}$ & $\begin{array}{l}\text { All tables dirty } \\
\text { and broken }\end{array}$ \\
\hline Quality and maintenance level of toilets & Flush toilet and clean & $\begin{array}{l}\text { Squatting toilet } \\
\text { and clean }\end{array}$ & $\begin{array}{l}\text { Flush toilet } \\
\text { but dirty }\end{array}$ & $\begin{array}{l}\text { Squatting toilet } \\
\text { but dirty }\end{array}$ \\
\hline $\begin{array}{l}\text { Quality and maintenance level of children } \\
\text { playground facilities }\end{array}$ & $\begin{array}{l}\text { All of them clean } \\
\text { and whole }\end{array}$ & $\begin{array}{l}\text { Most of them } \\
\text { clean and whole }\end{array}$ & $\begin{array}{l}\text { Most of them } \\
\text { dirty and broken }\end{array}$ & $\begin{array}{l}\text { All of them dirty } \\
\text { and broken }\end{array}$ \\
\hline Quality and maintenance level of sport facilities & $\begin{array}{l}\text { All of them clean } \\
\text { and whole }\end{array}$ & $\begin{array}{l}\text { Most of them } \\
\text { clean and whole }\end{array}$ & $\begin{array}{l}\text { Most of them } \\
\text { dirty and broken }\end{array}$ & $\begin{array}{l}\text { All of them dirty } \\
\text { and broken }\end{array}$ \\
\hline Level of shade at picnic spot ${ }^{b}$ & 4 & 3 & 2 & 1 \\
\hline General cleanliness ${ }^{c}$ & 4 & 3 & 2 & 1 \\
\hline Security level at site & $\begin{array}{l}\text { Full sense } \\
\text { of security }\end{array}$ & $\begin{array}{l}\text { Some worry in } \\
\text { remote areas }\end{array}$ & $\begin{array}{l}\text { Worry to } \\
\text { visit site }\end{array}$ & $\begin{array}{l}\text { No sense of } \\
\text { security at all }\end{array}$ \\
\hline
\end{tabular}

aThe numbers delineated levels of service on dimensions match the scores 1-4, where the score 1means "lowest level of service", score 4 means "highest level of service". 'Level of shade at the site is depicted by means of photographs whose numbers match the scores $1-4$, where the score 1 means "low level of shade", score 4 means "high level of shade". "Level of general cleanliness at the site is depicted by means of photographs whose numbers match the scores 1-4, where the score 4 means "very clean", the score 1 means "very dirty". 
Visitors remarked two different values as the minimum and ideal acceptable level for each one of the indicators. The minimum ideal acceptable service level for each of the indicators was identified according to the degree of consensus among visitors. In other words, values which conform to the largest group of visitors were defined as the minimum acceptable level and ideal acceptable level for each indicator.

Many of these indicators have quantitative characteristics such as "time sent searching for a parking space"; therefore, the levels of them can be measured with a numerical scale. Besides this, two indicators (degree of shading in picnic grounds and cleanliness) have qualitative characteristics. In such cases, computer simulation modelling is used to measure these indicators, which involves using software to manipulate and create visuals [44] [45]. Visuals provide a realistic and cognitively easy assessment of indicators so they provide convenience for respondents to choose conditions that would be like [46] [47]. This technique have widely preferred for describing environmental or social indicator impacts [26] [44] [46] [48]-[51]. Computer simulation modeling was used to prepare two series of photographs which represent two qualitative indicators; shading and cleanliness range. The number and size of thrashes in the images were measured by 4-color-photographs representing level of cleanliness of the site. The number of trashes was detected at four different levels, which increase arithmetically. The cleanliness simulation series were presented in Figure 3. The second simulation series, represented the shading indicator levels, were also prepared with the same technique.

Identifying perceived level of service and satisfaction degree of visitors: In order to identify perceived level of service and satisfaction degree of visitors, the site-based method was implemented. The perceived level represents the level, which visitors decided taking into account during their visiting experience. The visitors' degree of satisfaction from each indicator and also overall satisfaction from the visit were measured by the five-point likert-type. In this response scale the lowest level (1) signifies dissatisfaction and the highest level (5) means full satisfaction.

Identifying level of service: This process includes several steps. First, the contribution of the different indicators to the visitor's overall satisfaction from the visit is identified with a statistical analyses based on Ordinal Logistic Model (OLM). This model analyzes the possibility of different levels of overall satisfaction as a function of the satisfaction levels from each one of the indicators. The results of the model reveal the key indicators that influence overall satisfaction to the greatest degree in recreational site. In order to elicit the relative importance of the key indicators influencing overall level of satisfaction, Likelihood-Ratio Chi Square test is carried out. The relations between source Likelihood-Ratio Chi Square and Whole Model Likelihood Chi Square Difference and also standardized coefficient is investigated to answer the question of which of the key indicators have a greater effect on the overall satisfaction in this regression analyze.

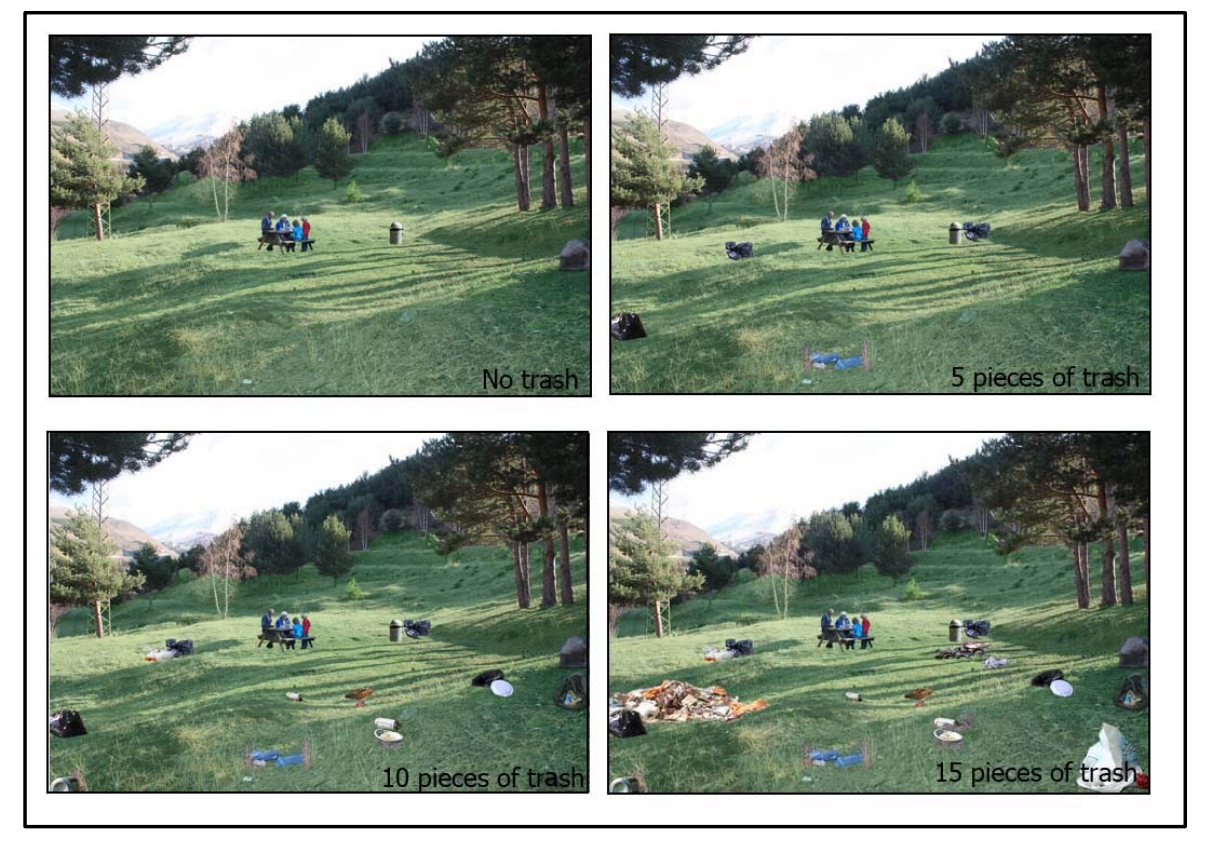

Figure 3. Simulation series which is represented shading indicator levels. 
Finally, the overall level of service is calculated by the following formula.

$$
\operatorname{LOS}_{j}=\sum_{i=1}^{n} \frac{\alpha_{i}\left(x_{i j}-x_{i l}\right) /\left(x_{i u}-x_{i l}\right)}{n}=\sum_{i=1}^{n} \frac{\alpha_{i} \operatorname{LOS}_{i j}}{n}
$$

where $x_{i j}$ is the perceived level of indictor $i, x_{i u}$ is the ideal level of indicator $i$ and $x_{i l}$ is the minimum acceptable level of indicator $i$. Therefore $\left(x_{i u}-x_{i l}\right)$ is the tolerance range along indicator $i . \alpha_{i}$ is a coefficient that states the relative importance of indicator $i$ originated in the logistic model and $n$ is the number of indicators that are the most important on the overall satisfaction identified by OLM. Usually LOS value varies from 0 to 1 scale.

\section{Results}

Demographic profile of respondents: Table 3 summarizes the demographic profile of the study respondents. Most of the respondents were female (57.8\%), 18 - 34 (45.2\%) or 35 - 49 (37.3\%) age groups, had at least a university degree (58.4\%), lived in Erzurum city (85.5), married (73.5), had 1 - 2 children (45.2) and had a household income less than 2000 TL (38.6\%) or between 2001 TL and 4000 TL (45.2\%).

The minimum acceptable level and the ideal level of the tolerance range: In order to identify a minimum acceptable level and ideal level of the tolerance range, the generic method was implemented. For this purpose, visitors were asked to evaluate alternative four different level of each indicator and they decided on which one was describing the preferred (ideal) level of each indicator and which indicator was describing the conditions that makes it unacceptable to visit that site (minimum acceptable level). At least $40 \%$ of the respondents agreed at the same degree of satisfaction from an indicator, which was approved as representative and reasonable. In this study, the general cleanliness indicator and level of shade was measured with four photographs depicting the number and size of thrashes 0 to 15 pieces of thrashes with the number of trashes doubling in each image (i.e. 0 , 5,10 and 15) and the size of space covered by shadow doubling in each image (i.e. $0 \%$ of site, $25 \%$ of site, $50 \%$ of site, $75 \%$ of site).

Table 4 shows the majority of respondents' opinion about the minimum acceptable level and ideal level of the indicators. Most visitors reported that time searching for a parking space and picnic spot for 5 - 10 minute was tolerance threshold, while up to 5 minute was ideal duration, the playground and sport facilities need to be at least $1-2$ units and preferably $3-4$ units at the picnic site, proximity of the adjacent group $5-10 \mathrm{~m}$ was the

Table 3. Description of survey respondents $(N=166)$.

\begin{tabular}{|c|c|c|c|}
\hline \multicolumn{4}{|c|}{ "Socio-demographic variables percent (\%)" } \\
\hline Gender & $\%$ & Family status & $\%$ \\
\hline Female & 57.8 & Married & 73.5 \\
\hline Male & 42.2 & Bachelor & 26.5 \\
\hline Age & & Number of children under 18 & $\%$ \\
\hline $18-34$ & 45.2 & None & 34.3 \\
\hline $35-49$ & 37.3 & $1-2$ & 45.2 \\
\hline 50 or above & 17.5 & 3 & 16.9 \\
\hline Educational level & $\%$ & $>3$ & 3.6 \\
\hline Primary school & 10.2 & Household income & $\%$ \\
\hline High school & 31.3 & Less than 2000 TL (less than $668 €$ ) & 38.6 \\
\hline University or above & 58.4 & 2001 TL-4000 TL (669 € - $1336 €)$ & 45.2 \\
\hline Place of residence & $\%$ & 4001 TL-7000 TL $(1337 €-2338 €)$ & 12.7 \\
\hline Erzurum city & 85.5 & More than 7001 TL (more than $2339 €$ ) & 3.6 \\
\hline Another city & 14.5 & & \\
\hline
\end{tabular}


Table 4. Tolerance range for the Erzurum Urban Forest.

\begin{tabular}{|c|c|c|c|c|c|c|}
\hline \multirow{2}{*}{ Indicators } & \multicolumn{3}{|c|}{ Minimum acceptable level } & \multicolumn{3}{|c|}{ Ideal level } \\
\hline & & Score & $\%$ & & Score & $\%$ \\
\hline Time searching for a parking space & $5-10 \mathrm{~min}$ & 3 & 51.8 & Up to 5 min & 4 & 68.1 \\
\hline Time searching for a picnic spot & $5-10 \mathrm{~min}$ & 3 & 50.6 & Up to 5 min & 4 & 47.0 \\
\hline Number of available picnic tables at picnic site & $1 / 3$ & 2 & 42.8 & $2 / 3-1 / 3$ & 3 & 42.2 \\
\hline Quantity of children's playground facilities & $1-2$ & 2 & 47.0 & $3-4$ & 3 & 53.6 \\
\hline Quantity of sport facilities & $1-2$ & 2 & 52.4 & $3-4$ & 3 & 48.2 \\
\hline Distance from signs to signs & More than $200 \mathrm{~m}$ & 1 & 42.2 & $40-60 \mathrm{~m}$ & 3 & 48.2 \\
\hline Distance from picnic spot to adjacent group & $5-10 m$ & 2 & 44.6 & More than $20 \mathrm{~m}$ & 4 & 43.4 \\
\hline Distance from picnic spot to parking & $15-30 \mathrm{~m}$ & 2 & 44.0 & $5-15 m$ & 3 & 42.2 \\
\hline Distance from picnic spot to toilets & $60-100 m$ & 2 & 42.2 & $40-60 \mathrm{~m}$ & 3 & 44.6 \\
\hline $\begin{array}{l}\text { Quality and maintenance level of children } \\
\text { playground facilities }\end{array}$ & $\begin{array}{l}\text { Most of them clean } \\
\text { and whole }\end{array}$ & 3 & 50 & $\begin{array}{l}\text { All of them clean } \\
\text { and whole }\end{array}$ & 4 & 76.5 \\
\hline $\begin{array}{l}\text { Quality and maintenance level of } \\
\text { sport facilities }\end{array}$ & $\begin{array}{l}\text { Most of them clean } \\
\text { and whole }\end{array}$ & 3 & 50 & $\begin{array}{l}\text { All of them clean } \\
\text { and whole }\end{array}$ & 4 & 76.5 \\
\hline Level of shade at picnic spot ${ }^{\mathrm{b}}$ & 2 & 2 & 48.8 & 3 & 3 & 45.2 \\
\hline Distance from picnic spot to water taps & $10-20 \mathrm{~m}$ & 2 & 42.8 & Up to $5 \mathrm{~m}$ & 4 & 42.2 \\
\hline Quality and maintenance level of toilets & Squatting toilet and clean & 3 & 54.8 & $\begin{array}{l}\text { Squatting toilet } \\
\text { and clean }\end{array}$ & 3 & 72.9 \\
\hline Quality and maintenance level of tables & $\begin{array}{l}\text { Most of them clean } \\
\text { and whole }\end{array}$ & 3 & 50 & $\begin{array}{l}\text { All of them clean } \\
\text { and whole }\end{array}$ & 4 & 76.5 \\
\hline Security level at site & Full sense of security & 4 & 51.8 & Full sense of security & 4 & 85.5 \\
\hline General cleanliness & 3 & 3 & 59.6 & 4 & 4 & 94.6 \\
\hline
\end{tabular}

tolerance threshold and more than 20 m was ideal distance, shaded areas at a picnic spot should not be less than $25 \%$, while $50 \%$ of the area should ideally was in shade. It is revealed that there was no difference between the minimum acceptable level and the ideal level from two indicators, which were the quality, and maintenance level of toilets and security level at site. Namely, a majority of the visitors did not approve any decrease in the quality of both of indicators. This means that there was no tolerance range for these indicators.

Identifying perceived level of service and satisfaction degree of visitors: In order to identify a perceived level of service by the site-based method, visitors were asked to evaluate alternative four different level of each indicator and decide on the one described the actual level of each indicator according to their recreation experience. Then, visitors were asked to give a value of their satisfaction from each indicator, which was exposed during recreation experience. The visitors' degree of satisfaction from each indicator and also the overall satisfaction from the visit, were measured by the five-point likert-type.

Visitor comments about perceived level of service were exhibited in Table 5. Most visitors experienced and predicated that the only five indicators levels were at score 3. According to levels of service by indicators which were shown Table 2, the numbers delineated levels of service on dimensions match the scores 1-4, where the score 1 means "lowest level of service", score 4 means "highest level of service". It is inferred that although none of the indicators were experienced at the highest level, the indicators; "time searching for a parking space", "distance from picnic spot to adjacent group", "level of shade at picnic spot", "security level at site" and "general cleanliness" were experienced higher than other indicators. In addition to these, "number of available picnic tables at picnic site", "distance from signs to signs", "distance from picnic spot to toilets" and "quality and maintenance level of toilets" were experienced at the lowest level by respondents.

The conclusions in Table 6, expressed that none of the indicators was perceived to be at the "satisfied" or 
Table 5. Perceived levels of Erzurum Urban Forest.

\begin{tabular}{|c|c|c|c|}
\hline Indicators & Perceived levels of service & Score & $\%$ \\
\hline Time searching for a parking space & $5-10 \min$ & 3 & 42.2 \\
\hline Time searching for a picnic spot & $10-15$ min & 2 & 40.4 \\
\hline Number of available picnic tables at picnic site & Less than a third & 1 & 48.2 \\
\hline Quantity of children's playground facilities & 1 - 2 in area & 2 & 66.3 \\
\hline Quantity of sport facilities & $1-2$ in area & 2 & 93.4 \\
\hline Distance from signs to signs & More than $200 \mathrm{~m}$ & 1 & 90.4 \\
\hline Distance from picnic spot to adjacent group & $10-20 \mathrm{~m}$ & 3 & 63.3 \\
\hline Distance from picnic spot to parking & $15-30 m$ & 2 & 49.4 \\
\hline Distance from picnic spot to toilets & More than $100 \mathrm{~m}$ & 1 & 50.6 \\
\hline Quality and maintenance level of children playground facilities & Most of them dirty and broken & 2 & 75.3 \\
\hline Quality and maintenance level of sport facilities & Most of them dirty and broken & 2 & 75.3 \\
\hline Level of shade at picnic spot & 3 & 3 & 55.4 \\
\hline Distance from picnic spot to water taps & $10-20 m$ & 2 & 55.4 \\
\hline Quality and maintenance level of toilets & Squatting toilet but dirty & 1 & 71.1 \\
\hline Quality and maintenance level of tables & Most of them dirty and broken & 2 & 59.0 \\
\hline Security level at site & Some worry in remote areas at site & 3 & 53.0 \\
\hline General cleanliness & 3 & 3 & 52.4 \\
\hline
\end{tabular}

Table 6. Distribution of visitors according to degree of satisfaction from different indicators.

\begin{tabular}{|c|c|c|c|c|c|c|}
\hline \multirow{2}{*}{ Indicators } & \multicolumn{6}{|c|}{ Satisfaction degree ${ }^{a}$ (percent) } \\
\hline & 1 & 2 & 3 & 4 & 5 & Aver. score \\
\hline Time searching for a parking space & 10.8 & 20.5 & 40.8 & 19.5 & 8.4 & 2.95 \\
\hline Time searching for a picnic spot & 22.3 & 24.5 & 40.7 & 7.7 & 4.8 & 2.48 \\
\hline Number of available tables & 11.4 & 46.4 & 27.1 & 14.5 & 0.6 & 2.46 \\
\hline Quantity of children's playground facilities & 10.8 & 54.2 & 22.9 & 11.4 & 0.6 & 2.37 \\
\hline Quantity of sport facilities & 31.9 & 42.8 & 16.9 & 7.2 & 1.2 & 2.03 \\
\hline Quantity of signs & 10.8 & 46.4 & 22.9 & 18.7 & 1.2 & 2.53 \\
\hline Distance from picnic spot to adjacent group & 4.2 & 22.3 & 42.8 & 27.1 & 3.6 & 3.04 \\
\hline Distance from picnic spot to parking & 6.6 & 31.9 & 45.8 & 13.3 & 2.4 & 2.73 \\
\hline Distance from picnic spot to toilets & 9.0 & 43.4 & 33.7 & 11.4 & 2.4 & 2.55 \\
\hline Distance from picnic spot to water taps & 6.6 & 41.6 & 36.1 & 12.0 & 3.6 & 2.64 \\
\hline Distance from picnic spot to garbage cans & 13.9 & 43.7 & 23.9 & 16.1 & 2.4 & 2.49 \\
\hline Quality of tables (clean and whole) & 7.2 & 52.4 & 28.9 & 10.2 & 1.2 & 2.46 \\
\hline Quality and maintenance level of children playground facilities & 9.6 & 53.6 & 27.1 & 8.4 & 1.2 & 2.38 \\
\hline Quality and maintenance level of sport facilities & 16.9 & 48.8 & 25.9 & 7.8 & 0.6 & 2.27 \\
\hline Quality and maintenance level of toilets & 24.7 & 44.6 & 19.9 & 10.2 & 0.6 & 2.17 \\
\hline General cleanliness & 5.4 & 36.1 & 42.2 & 15.1 & 1.2 & 2.70 \\
\hline Security level at site & 11.4 & 31.3 & 40.2 & 16.5 & 0.6 & 2.63 \\
\hline Level of shade at site & 2.4 & 25.9 & 49.4 & 18.7 & 3.6 & 2.95 \\
\hline Crowding perception & 11.4 & 19.5 & 40.2 & 18.7 & 10.2 & 2.97 \\
\hline General satisfaction & 3.0 & 24.7 & 51.8 & 17.5 & 3.0 & 2.93 \\
\hline
\end{tabular}

${ }^{\mathrm{a}} 1$ = completely dissatisfied, 2 = dissatisfied, 3 = moderately satisfied, 4 = satisfied and 5 = completely satisfied. 
"completely satisfied" degree by visitors. Most of the respondents were "moderately satisfied" from time searching for a parking space (40.8\%), time searching for a picnic spot (40.7\%), distance from picnic spot to adjacent group (42.8\%), distance from picnic spot to parking (45.8\%), general cleanliness (42.2\%), security level at site (40.2\%), level of shade at site (49.4\%), crowding perception (40.2\%), general satisfaction (51.8\%). On the other hand, quality, quantity, maintenance and proximity of most facilities were proved unsatisfactory. Most of the respondents were "dissatisfied" from number of available tables (46.4), quantity of children's playground facilities (54.2), quantity of sport facilities (42.8), quantity of signs (46.4), distance from picnic spot to toilets (43.4), distance from picnic spot to water taps (41.6), distance from picnic spot to garbage cans (43.7), quality of tables (clean and whole) (52.4), quality and maintenance level of children playground facilities (53.6), quality and maintenance level of sport facilities (48.8), quality and maintenance level of toilets (44.6). The findings reveal that only 4 of the all indicators were reported to be at "moderately satisfied" degree. Most of the indicators were dissatisfying for visitors. Correspondingly, it was determined that the average scores of these indicators were closer to the "dissatisfied" degree (2). The average scores were examined, it was shown that the satisfying degree from each of the indicator was between at "dissatisfied" (2) and "moderately dissatisfied" (3) level. The lowest satisfaction averages pertain to quantity of sport facilities (2.03), quality and maintenance level of toilets (2.17) and the highest level of satisfaction averages pertain to distance from picnic spot to adjacent group (3.04) and crowding perception (2.97).

Level of Service: In order to calculate LOS (Level of Service), the probability of different levels of overall satisfaction as a function of the satisfaction levels from each one of the indicators were analyzed by using Ordinal Logistic Model (OLM). Both the dependent and the independent variables, which were at the original five-point survey scale, were used to evaluate visitor satisfaction and they were converted into three values. These three values converted respectively: 1, dissatisfied (converted values 1 "Completely dissatisfied” and 2 "Dissatisfied”); 3, moderately satisfied; 5, satisfied (converted values 4 "Satisfied” and 5 "Completely Satisfied”).

All of the indicators, which were designated in Table 4 were measured with using OLM. The results are indicated that, only four indicators of overall satisfaction were at the greatest degree. These indicators, which are "distance from picnic spot to parking”, "distance from picnic spot to toilets", "quantity of children's playground facilities", and "level of shade at picnic spot" are presented in Table 7. The effects of intensity on the overall satisfaction (depended variable) were deduced from the size of parameter estimates, while the direction of the effect of independent variables on overall satisfaction level was revealed from the signs of estimates. This means that negative sign of the parameters probably causes the decrease of overall satisfaction. Consequently, the parameters, which are "distance from picnic spot to toilets" and "quantity of children's playground facilities", decrease of overall satisfaction while "distance from picnic spot to parking" and "level of shade at picnic spot" have a positive contribution to the overall satisfaction.

The overall level of service is the average weighted sum of these indicators. The weighting indicates the importance of the indicators, as derived from the Logistic Model. The relation between Likelihood-Ratio Chi Square for each indicator in the model and Whole Model Likelihood Chi Square Difference was regarded to be the convenient measure of the relative importance of the indicator. Table 8 shows the estimations, which indicate the relative importance of indicators' effect on overall level of visitor satisfaction.

Also, the indicators that were identified as the most important on overall satisfaction were compared with their perceived levels, minimum acceptable levels and ideal levels (Table 9). It is shown that only perceived level of "level of shade at picnic spot" is equal to the ideal level, while the other indicators' perceived levels are below the ideal levels.

Table 7. Contribution of different indicators to overall satisfaction from the visit.

\begin{tabular}{lccc}
\hline \multicolumn{1}{c}{ Variable } & Estimate & Standard error & $\chi^{2}$ test \\
\hline Constant $=1$ & 4.088 & 1.355 & $9.106^{\mathrm{a}}$ \\
Constant $=2$ & 6.444 & 1.408 & $20.942^{\mathrm{a}}$ \\
Distance from picnic spot to parking & -0.551 & 0.215 & $6.584^{\mathrm{a}}$ \\
Distance from picnic spot to toilets & -0.390 & 0.192 & $4.120^{\mathrm{b}}$ \\
Quantity of children's playground facilities & -0.473 & 0.229 & $4.277^{\mathrm{b}}$ \\
Level of shade at picnic spot $^{\mathrm{b}}$ & 0.708 & 0.200 & $12.517^{\mathrm{b}}$ \\
\hline
\end{tabular}

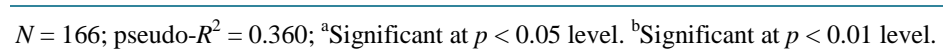


Table 8. Relative importance of satisfaction indicators influencing overall level of satisfaction.

\begin{tabular}{lccc}
\hline Indicators & Likelihood ratio & $\begin{array}{c}\text { Relation between source likelihood-ratio } \\
\text { chi square and whole model likelihood } \\
\text { chisquare difference }\end{array}$ & Standardized coeff. $\boldsymbol{\alpha}_{\boldsymbol{i}}$ \\
\hline Distance from picnic spot to parking & 20.191 & 0.165 & 1.22 \\
$\begin{array}{l}\text { Distance from picnic spot to toilets } \\
\begin{array}{l}\text { Quality and maintenance level of } \\
\text { children playground facilities }\end{array}\end{array}$ & 2.663 & 0.022 & 0.163 \\
$\begin{array}{l}\text { Level of shade at site } \\
\text { Whole model }\end{array}$ & 7.117 & 0.058 & 0.430 \\
\hline
\end{tabular}

Table 9. The most important indicators' influence on overall level of satisfaction.

\begin{tabular}{lcccccc}
\hline Indicators & Perceived level & Score & Min. accep. level & Score & Ideal level & Score \\
\hline Distance from picnic spot to parking & $15-30 \mathrm{~m}$ & 2 & $15-30 \mathrm{~m}$ & 2 & $5-15 \mathrm{~m}$ & 3 \\
$\begin{array}{l}\text { Distance from picnic spot to toilets } \\
\begin{array}{l}\text { Quality and maintenance level of } \\
\text { children playground facilities }\end{array}\end{array}$ & $\begin{array}{c}\text { Most of them dirty } \\
\text { and broken }\end{array}$ & 2 & $\begin{array}{c}\text { Most of them } \\
\text { clean and whole }\end{array}$ & 3 & $\begin{array}{c}\text { All of them } \\
\text { clean and whole }\end{array}$ & 4 \\
Level of shade at site & 3 & 3 & 2 & 2 & 3 & 3 \\
\hline
\end{tabular}

Finally the overall level of service for the Erzurum Urban Forest was calculated by using LOS formula as follows:

$$
\operatorname{LOS}_{j}=\sum_{i=1}^{n} \frac{\alpha_{i}\left(x_{i j}-x_{i i}\right) /\left(x_{i u}-x_{i l}\right)}{n}=\frac{1.22 \times \frac{(2-2)}{(3-2)}+0.163 \times \frac{(1-2)}{(3-2)}+0.430 \times \frac{(2-3)}{(4-3)}+2.20 \times \frac{(3-2)}{(3-2)}}{4}=0.40
$$

where;

$x_{i j}=$ the perceived level of indictor $i$.

$x_{i u}=$ the ideal level of indicator $i$.

$x_{i l}=$ the minimum acceptable level of indicator $i$.

Therefore $\left(x_{i u}-x_{i l}\right)$ is the tolerance range along indicator $i$.

$\alpha_{i}=$ a coefficient which states the relative importance of indicator $i$ originated in the logistic model.

$n=$ the number of indicators which are the most important on the overall satisfaction identified by OLM.

Usually LOS value varies from 0 to 1 scale. This means that if the value of LOS closer to 1 , the level of service should be evaluated as at the high quality. The values, obtained as a result of several statistical analyses, were calculated by LOS formula. The level of service for Erzurum Urban Forest calculated according to the expression was 0.40. It is inferred from this value that the level of service in Erzurum Urban Forest is below the moderate level.

\section{Discussion}

The aim of this study is to determine recreational level of service of Erzurum Urban Forest, which is located in close proximity to the city center and preferred especially for picnics by the locals.

For this purpose, possible dimensions of satisfaction for picnic recreation and the 17 indicators representing these dimensions were identified. 200 respondents were sampled in the survey and 166 questionnaires were found useable. In order to ensure variety in response and filling in questionnaire without being under the influence, the members of different families conducted the questionnaires and questionnaires were self-administered. The purpose of maximum variety sampling is not to generalize the universe by providing diversity; it is to find the similarities and partnerships between the diverse situations [52]. From these identified indicators the socio-demographic variables of visitors, tolerance range, perceived levels and satisfaction degree were inferred. Computer simulation modeling was used to measure two qualitative indicators that were "shade at picnic spot" 
and "general cleanliness". Each simulation was presented as $20 \mathrm{~cm} \times 15 \mathrm{~cm}$ in size and high resolution for an easy comprehension by visitors. The tolerance range between minimum acceptable level and high level of service was identified by the generic method while the perceived level and satisfaction degree were identified by the site based method for those indictors in which the degree of user consensus exceeded $40 \%$.

It was inferred from tolerance range analyze, most visitors reported that time searching for a parking space and picnic spot for 5 - 10 minute was the tolerance threshold, while up to 5 minute was an ideal duration. Indeed, the majority of visitors were observed during the site survey that they carried heavy picnic supplies from parking area to picnic site. It is estimated that the type of visit and usage habits to be effective on visitors' tolerance range. Most of the visitors notified that the playground and sport facilities need to be at least 1 - 2 units and preferably 3 - 4 units at the picnic site. This result is interpreted with demographic profile of respondents, most of them were 18 - 34 (45.2\%) or 35 - 49 (37.3\%) age groups and they had 1 - 2 children (45.2). For most visitors proximity of the adjacent group 5 - $10 \mathrm{~m}$ was the tolerance threshold and more than $20 \mathrm{~m}$ was ideal distance. This finding is not only important for designing in accordance with the physical capacity but also important for managing social capacity of the site. More clearly it is expressed that with the increase of crowding, probably the distance of adjacent picnic spot (picnic table or only a rug brought by visitors) will be shortened.

None of the indicators was perceived to be at "satisfied" or "completely satisfied" levels by visitors, and also except "the shade of site" indicator, the perceived level of any indicator is not equal to their ideal level. In addition to these results, the perceived level of 8 indicators ("Time searching for a picnic spot" "Number of available picnic tables at picnic site”, "Distance from picnic spot to toilets” "Quality and maintenance level of children playground facilities” "Quality and maintenance level of sport facilities” "Quality and maintenance level of toilets" “Quality and maintenance level of tables" "Security level at site”) were determined to be below minimum acceptable level. According to these results, it can be stated that the quality and the number of recreational facilities, service facilities and sanitary facilities from the identified dimensions of satisfaction of the site were insufficient in terms of the quality of recreation experience. It was determined that the consensus for perceived levels of related with "time searching” and "distance” indicators is lower than the others. This divergence is suspected that the visitors may have stayed different locations of site and may have reached different times of a day. The questionnaires were conducted with 1 individual from each family to ensure diversity of survey and to increase the reliability.

It was inferred from satisfaction degree analyze that; The average scores of indicators, correlated with perceived level analyze results, revealed that the satisfying degree from each of the indicator was between at "dissatisfied" and "moderately dissatisfied" level. It can be seen clearly that the service quality is lower than the standards of determined indicators and this physical deficiency does not only restrict the physical capacity but also reduces the level of satisfaction of the visitors, which affects the social capacity.

Ordinal Logistic Model (OLM) was used to identify the contribution of all indicators to the visitor's overall satisfaction; Likelihood-Ratio Chi Square test, Relation between source Likelihood-Ratio Chi Square and Whole Model Likelihood Chi Square Difference was used to identify the relative importance of the key indicators. By standardized coefficient in this regression analyze, which indicators have a greater effect on the overall satisfaction were identified.

The four indicators are important on the overall visitor satisfaction. One of these indicators "the distance from picnic spot to parking" and "level of shade at picnic spot" have positive effect, while "the distance from picnic spot to toilets" and "quantity of children's playground facilities”, have negative effect on the overall satisfaction. It was observed that the some visitors prefer to park their cars on the road on the side of the picnic area rather than the parking area. On "The distance from picnic spot to parking” indicator, it was considered that this behavior was likely to be reflected as a positive effect. Also, the climatic condition of Erzurum City is estimated to contribute to these results. The continental (cold and temperate) climate is dominant, the altitude is over 2000 meters, during the summer months low and moderate winds are blowing in Erzurum City. For this reason, climatic comfort can be provided without the need for intensive shade in the picnic spots. As a result of these analyses it is clear that the distance from picnic spot to toilets is longer than preferred distance and the quantity of children's playground facilities is less than preferred. It is recommended to increase the satisfaction of visitors, increase the level of service by constructing another toilet introduce regular cleaning. In addition to these, redesign playground in the site and supplying maintenance were suggested.

LOS, ranging from 0 to 1 scale, was calculated as 0.40 for Erzurum Urban Forest. It is inferred from this value that the level of service in Erzurum Urban Forest is below the moderate level. This result also means that the 
physical and managing conditions are insufficient for optimum satisfaction level of visitors and recreational experience quality. Although it is not actually recreational use above the social capacity in the area, the social capacity is affected by the way of physical inadequacy and managerial inability. In fact, several authors have noted that crowding is not the only factor that affects the social capacity of the recreation experience, but there are also other factors that affect the quality of the recreation experience [53] [54]. However, previous studies was emphasized that each factor also does not have the same degree of impact on the quality of the recreation experience [11] [32].

Besides this, Fleishman and Feitelson, 2009 [11] applied the recreation level of service approach to forests in Israel. The results of the study, different from our study, reveal that four indicators; "time searching for a parking space", "number of available picnic tables at picnic site”, "quality and maintenance of tables" and "shade intensity at picnic spot” found significant effect on the overall satisfaction. Both studies are compared with each other; it is observed that the significant indicators are different. This discrepancy is thought to result from the demographic characteristics of the visitors. Indeed, Sayan and Karagüzel (2010) [55] analyzed the effect of visitors' demographics on the perceptions and Sayan et al. (2013) [56] analyzed the cultural influence on crowding norms in outdoor recreation. In both studies, significant differences between the satisfaction levels of different visitor groups were found.

\section{Conclusion}

Although the basis of LOS method constitutes the most important factors on the overall satisfaction of visitors, it should be noted that the other indicators have an impact on satisfaction. Consequently, it is thought to be the proper approach to enhance the great effected indicators on the overall satisfaction first and then to develop other indicators during the planning of visitor management.

\section{References}

[1] Miles, C.W.N. and Seabrooke, W. (2013) Recreational Land Management. Taylor \& Francis, 120.

[2] Pigram, J.J.J. and Jenkins, J.M. (1999) Outdoor Recreation Management. Psychology Press, 415.

[3] Dwyer, J.F., McPherson, E.G., Schroeder, H.W. and Rowntree, R.A. (1992) Assessing the Benefits and Costs of the Urban Forest. Journal of Arboriculture, 18, 227.

[4] Aikoh, T. and Wei, T. (2014) Monitoring the Number of Urban Forest Visitors and Their Attachment in Sapporo, Japan. The 7th International Conference on Monitoring and Management of Visitors in Recreational and Protected Areas (MMV), Tallinn, 242.

[5] Hammitt, W.E. (2002) Urban Forests and Parks as Privacy Refuges. Journal of Arboriculture, 28, 19.

[6] Arnberger, A. (2006) Recreation Use of Urban Forests: An Inter-Area Comparison. Urban Forestry \& Urban Greening, 4, 135. http://dx.doi.org/10.1016/j.ufug.2006.01.004

[7] Heer, C., Rusterhols, H.P. and Baur, B. (2003) Forest Perception and Knowledge of Hikers and Mountain Bikers in Two Different Areas in Northwestern Switzerland. Environmental Management, 31, 709. http://dx.doi.org/10.1007/s00267-003-3002-x

[8] Shindler, B.A., Brunson, M.W. and Stankey, G.H. (2002) Social Acceptability of Forest Conditions and Management Practices: A Problem Analysis. General Technical Report PNW-GTR-537.

[9] Papageorgiou, K. and Brotherton, I.A. (1999) Management Planning Framework Based on Ecological, Perceptual and Economic Carrying Capacity: The Case Study of Vikos-Aoos National Park, Greece. Journal of Environmental Management, 56, 271. http://dx.doi.org/10.1006/jema.1999.0285

[10] Cole, D.N. (2003) Carrying Capacity and Visitor Management: Facts, Values and the Role of Science. Special Session of George Wright Society Biennial Conference: Protecting Our Diverse Heritage: The Role of Parks, Protected Areas and Cultural Sites, San Diego, 43.

[11] Fleishman, L. and Feitelson, E. (2009) An Application of the Recreation Level of Service Approach to Forests in Israel. Landscape and Urban Planning, 89, 86-97. http://dx.doi.org/10.1016/j.landurbplan.2008.10.012

[12] Manning, R.E. and Lawson, S.R. (2002) Carrying Capacity as “Informed Judgment”: The Values of Science and the Science of Values. Environmental Management, 30, 157-168. http://dx.doi.org/10.1007/s00267-002-2772-x

[13] Wagar, J.A. (1964) The Carrying Capacity of Wildlands for Recreation. Forest Science Monographs, 7, 1-23.

[14] Manning, R.E. (2002) How Much Is Too Much? Carrying Capacity of National Parks and Protected Areas. In: Proceedings of the Conference on Monitoring and Management of Visitor Flows in Recreational and Protected Areas, 
Bodenkultur University, Vienna, 306-313.

[15] Shelby, B. and Heberlein, T.A. (1984) A Conceptual Framework for Carrying Capacity Determination. Leisure Sciences, 6, 433-451. http://dx.doi.org/10.1080/01490408409513047

[16] Göktuğ, T.H., Yildiz, N.D., Demir, M. and Bulut, Y. (2013) Taşıma Kapasitesi Kuramının Milli Parklarda OluşumGelişimve Modellenme Süreci. Journal of the Faculty of Agriculture, 44, 195-206.

[17] McCool, S. and Lime, D. (2001) Tourism Carrying Capacity: Tempting Fantasy or Useful Reality? Journal of Sustain Tourism, 9, 372-388. http://dx.doi.org/10.1080/09669580108667409

[18] Ceballos-Lascuráin, H. (1996) Tourism, Ecotourism and Protected Areas: The State of Nature-Based Tourism around the World and Guidelines for Its Development. IUCN Publications, Cambridge, 301. http://dx.doi.org/10.2305/iucn.ch.1996.7.en

[19] Whittaker, D., Shelby, B., Manning, R., Cole, D. and Haas, G. (2011) Capacity Reconsidered: Finding Consensus and Clarifying Differences. Journal of Park and Recreation Administration, 29, 1-20.

[20] Brown, P.J., Driver, B.L. and McConnell, C. (1978) The Opportunity Spectrum—Concept and Behavioral Information in Outdoor Recreation Resource Supply Inventories: Background and Application. In: Proceedings of the Integrated Inventories of Renewable Natural Resources Workshop, USDA Forest Service General Technical Report RM-55, Rocky Mountain Forest and Range Experiment Station, Ft. Collins, 73.

[21] Stankey, G.H., McCool, S.F. and Stokes, G.L. (1984) Limits of Acceptable Change: A New Framework for Managing the Bob Marshall Wilderness Complex. Western Wildlands, 10, 33-37.

[22] Graham, R., Nilsen, P. and Payne, R.J. (1988) Visitor Management in Canadian National Parks. Tourism Management, 9, 44-61. http://dx.doi.org/10.1016/0261-5177(88)90057-X

[23] Graefe, A.R., Kuss, F.R. and Vaske, J.J. (1990) Visitor Impact Management: A Review of Research. National Parks and Conservation Association, Washington DC.

[24] Hof, M. and Lime, D.W. (1997) Visitor Experience and Resource Protection Framework in the National Park System: Rationale, Current Status, and Future Direction. United States Department of Agriculture Forest Service General Technical Report, 29.

[25] Nilsen, P. and Tayler, G.A. (1997) Comparative Analysis of Protected Area Planning and Management Frameworks. United States Department of Agriculture Forest Service General Technical Report INT 49.

[26] Lawson, S.R., Manning, R.E., Valliere, W.A. and Wang, B. (2003) Proactive Monitoring and Adaptive Management of Social Carrying Capacity in Arches National Park: An Application of Computer Simulation Modeling. Journal of Environmental Management, 68, 305-313. http://dx.doi.org/10.1016/s0301-4797(03)00094-x

[27] Manning, R.E., Lime, D.W. and Hof, M. (1996) Social Carrying Capacity of Natural Areas: Theory and Application in the US National Parks. Natural Areas Journal, 16, 118-127.

[28] Manning, R.E. and Lime, D. (1996) Crowding and Carrying Capacity in the National Park System: Toward a Social Science Research Agenda. In: Lime, D.W., Ed., Crowding and Congestion in the National Park System: Guidelines of Management and Research, University of Minnesota Agricultural Experiment Station Publication 86, University of Minnesota, Minneapolis, 27.

[29] Arabatzis, G. and Grigoroudis, E. (2010) Visitors’ Satisfaction, Perceptions and Gap Analysis: The Case of DadiaLefkimi-Souflion National Park. Forest Policy and Economics, 12, 163-172. http://dx.doi.org/10.1016/j.forpol.2009.09.008

[30] Chang, C.Y. (1997) Using Computer Simulation to Manage the Crowding Problem in Parks: A Study. Landscape and Urban Planning, 37, 147-161. http://dx.doi.org/10.1016/s0169-2046(97)80001-1

[31] Herrick, T.A. and McDonald, C.D. (1992) Factors Affecting Overall Satisfaction with a River Recreation Experience. Environmental Management, 16, 243-247. http://dx.doi.org/10.1007/bf02393829

[32] Ormiston, D., Gilbert, A. and Manning, R.E. (1998) Indicators and Standards of Quality for Ski Resort Management. Journal of Travel Research, 36, 35-41. http://dx.doi.org/10.1177/004728759803600304

[33] Manning, R.E. (2011) Indicators and Standards in Parks and Outdoor Recreation. In: Budruk, M. and Phillips, R., Eds., Quality of Life Community Indicators for Parks, Recreation and Tourism Management, Springer, Dordrecht, 11-22. http://dx.doi.org/10.1007/978-90-481-9861-0 2

[34] Moore, S.A. and Polley, A. (2007) Defining Indicators and Standards for Tourism Impacts in Protected Areas: Cape Range National Park, Australia. Environmental Management, 39, 291-300. http://dx.doi.org/10.1007/s00267-005-0191-5

[35] Hammitt, W.E., McDonald, C.D. and Patterson, M.E. (1990) Determinants of Multiple Satisfaction for Deer Hunting. Wildlife Society Bulletin, 18, 331-337.

[36] Lawson, S.R. and Manning, R.E. (2002) Tradeoffs among Social, Resource, and Management Attributes of the Denali 
Wilderness Experience: A Contextual Approach to Normative Research. Leisure Sciences, 24, 297-312. http://dx.doi.org/10.1080/01490400290050754

[37] Manning, R., Wang, B., Valliere, W., Lawson, S. and Newman, P. (2002) Research to Estimate and Manage Carrying Capacity of a Tourist Attraction: A Study of Alcatraz Island. Journal of Sustainable Tourism, 10, 388-404. http://dx.doi.org/10.1080/09669580208667175

[38] Newman, P., Manning, R., Dennis, D. and McKonly, W. (2005) Informing Carrying Capacity Decision Making in Yosemite National Park, USA Using Stated Choice Modeling. Journal of Park and Recreation Administration, 23, 75-89.

[39] Itami, R.M. (2002) Estimating Capacities for Pedestrian Walkways and Viewing Platforms. A Report to Parks Victoria, 20.

[40] Zeithaml, V.A., Berry, L.L. and Parasuraman, A. (1996) The Behavioral Consequences of Service Quality. The Journal of Marketing, 60, 31. http://dx.doi.org/10.2307/1251929

[41] Sulek, J.M., Lind, M.R. and Marucheck, A.S. (1995) The Impact of a Customer Service Intervention and Facility Design on Firm Performance. Management Science, 41, 1763-1773. http://dx.doi.org/10.1287/mnsc.41.11.1763

[42] Dabholkar, P.A. (1995) A Contingency Framework for Predicting Causality between Customer Satisfaction and Service Quality. Advances in Consumer Research, 22, 101-108.

[43] Anonymous (2015) Republic of Turkey General Directorate of Forestry, Department of Education.

[44] Manning, R. and Freimund, W. (2004) Use of Visual Research Methods to Measure Standards of Quality for Parks and Outdoor Recreation. Journal of Leisure Research, 36, 557-579.

[45] Shelby, B., Vaske, J.J. and Donnelly, M.P. (1996) Standards and Natural Resources. Leisure Sciences, 18, $103-123$. http://dx.doi.org/10.1080/01490409609513276

[46] Needham, M.D., Rollins, R.B. and Wood, C.J. (2004) Site-Specific Encounters, Norms and Crowding of Summer Visitors at Alpine Ski Areas. International Journal of Tourism Research, 6, 421-437. http://dx.doi.org/10.1002/jtr.504

[47] Hall, T. and Roggenbuck, J. (2002) Response Format Effects in Questions about Norms: Implications for the Reliability and Validity of the Normative Approach. Leisure Sciences, 24, 325-338. http://dx.doi.org/10.1080/01490400290050772

[48] Inglis, G., Johnson, V. and Ponte, F. (1999) Crowding Norms in Marine Settings: A Case Study of Snorkeling on the Great Barrier Reef. Environmental Management, 24, 369-381. http://dx.doi.org/10.1007/s002679900240

[49] Freimund, W., Vaske, J., Donnelly, M. and Miller, T. (2002) Using Video Surveys to Access Dispersed Backcountry Visitors’ Norms. Leisure Sciences, 24, 349-362. http://dx.doi.org/10.1080/01490400290050790

[50] Wang, B. and Manning, R.E. (1999) Computer Simulation Modeling for Recreation Management: A Study on Carriage Road Use in Acadia National Park, Maine, USA. Environmental Management, 23, 193-203. http://dx.doi.org/10.1007/s002679900179

[51] Needham, M.D., Szuster, B.W. and Bell, C.M. (2011) Encounter Norms, Social Carrying Capacity Indicators, and Standards of Quality at a Marine Protected Area. Ocean \& Coastal Management, 54, 633-641. http://dx.doi.org/10.1016/j.ocecoaman.2011.06.004

[52] Yildirim, A. and Şimşek, H. (2006) Sosyal Bilimlerde Nitel Arastirma Yöntemleri. Seçkin Yayıncılık.

[53] Schreyer R., Lime, D.W. and Williams, D.R. (1984) Characterizing the Influence of Past Experience on Recreation Behavior. Journal of Leisure Research, 16, 34-50.

[54] Manning, R.E. and Lime, D.W. (2000) Defining and Managing the Quality of Wilderness Recreation Experiences. In: Cole, D.N., McCool, S.F., Borrie, W.T. and O’Loughlin, J., Eds., Wilderness Science in a Time of Change Conference: Volume 4, US Department of Agriculture, Forest Service, Rocky Mountain Research Station, Ogden, 13.

[55] Sayan, S. and Karagüzel, O. (2010) Problems of Outdoor Recreation: The Effect of Visitors' Demographics on the Perceptions of Termessos National Park, Turkey. Environmental Management, 45, 1257-1270. http://dx.doi.org/10.1007/s00267-010-9500-8

[56] Sayan, S., Krymkowski, D.H., Manning, R.E., Valliere, W.A. and Rovelstad, E.L. (2013) Cultural Influence on Crowding Norms in Outdoor Recreation: A Comparative Analysis of Visitors to National Parks in Turkey and the United States. Environmental Management, 52, 493-502. http://dx.doi.org/10.1007/s00267-013-0076-y 